\title{
Integrating Plant Essential Oils and Kaolin for the Sustainable Management of Thrips and Tomato Spotted Wilt on Tomato
}

\author{
Stuart R. Reitz, USDA-ARS-CMAVE, 6383 Mahan Dr., Tallahassee, FL 32308 USA; Giuseppina Maiorino, Uni- \\ versità degli Studi della Basilicata, Potenza, Italy; Steve Olson and Richard Sprenkel, North Florida Research and \\ Education Center, University of Florida, 155 Research Rd., Quincy, FL 32351 USA; Aniello Crescenzi, Università \\ degli Studi della Basilicata, Potenza, Italy; and M. Timur Momol, North Florida Research and Education Center, \\ University of Florida, 155 Research Rd., Quincy, FL 32351 USA
}

\begin{abstract}
Reitz, S. R., Maiorino, G., Olson, S., Sprenkel, R., Crescenzi, A., and Momol, M. T. 2008. Integrating plant essential oils and kaolin for the sustainable management of thrips and tomato spotted wilt on tomato. Plant Dis. 92:878-886.

Thrips-vectored Tomato spotted wilt virus is one of the most devastating pest complexes affecting tomato in the southern United States and elsewhere. Field trials were conducted over 2 years to determine the effects of volatile plant essential oils and kaolin-based particle films on the incidence of tomato spotted wilt and population dynamics of Frankliniella spp. thrips. The essential oils, geraniol (a monoterpene constituent of various plant essential oils), lemongrass (Cymbopogon flexuosus) oil, and tea tree (Melaleuca alternifolii) oil, were compared with a standard insecticide treatment and an untreated control. All treatments were applied with and without kaolin, in a $5 \times 2$ factorial design. Although the treatments did not clearly affect the abundance of vector species, there were treatment differences in the incidence of tomato spotted wilt. When combined with kaolin, the three essential oils reduced tomato spotted wilt incidence by 32 to $51 \%$ in 2005 and by 6 to $25 \%$ in 2006 compared with the control. In both years, tea tree oil plus kaolin reduced tomato spotted wilt as well as the standard insecticide treatments. Overall, kaolin significantly increased yield by over $26 \%$ compared to treatments without kaolin. When applied with kaolin, the three essential oils produced yields similar to the insecticide standard. Therefore, naturally occurring products, such as essential oils and kaolin, could be used successfully to reduce insecticide use on tomatoes.
\end{abstract}

Additional keywords: Frankliniella bispinosa, F. fusca, F. occidentalis

Thrips-transmitted Tomato spotted wilt virus (TSWV) is one of the most important pest complexes affecting tomato and other vegetable crops in the southern United States (5) as well as globally (51). Over the past two decades, severe epidemics of tomato spotted wilt (TSW), including complete crop loss, have frequently occurred on tomato. When epidemics of TSW began occurring in the southern United States during the late 1980s, tomato growers initially responded with applications of broad-spectrum insecticides on a near calendar basis, with up to 12 to 16 applications per season, in attempts to control thrips and TSW. This intensive insecticide regime has been practiced despite research showing that most losses from TSW are the result of primary infections from viruliferous thrips dispersing

Corresponding author: Stuart Reitz

E-mail: stuart.reitz@ars.usda.gov

Accepted for publication 5 February 2008.

doi:10.1094/PDIS-92-6-0878

This article is in the public domain and not copyrightable. It may be freely reprinted with customary crediting of the source. The American Phytopathological Society, 2008. into crop fields from surrounding vegetation $(25,41)$. Recently, integrated approaches that combine the use of ultraviolet reflective mulch, plant systemic acquired resistance inducers, and insecticides have led to reductions in the incidence of TSW in field grown tomatoes $(38,50)$. While these programs have been successful, they still rely on expensive inputs that pose environmental concerns, and the use of a limited suite of insecticides poses the risk of developing insecticide resistance. Therefore, there is still a need for alternative tactics that will help to manage thrips and TSW in a sustainable, economical, and environmentally sound manner.

The virus is acquired only by the larval stage of thrips, and virtually all plant-toplant transmission is accomplished by the mobile adult stage (66). Because TSWV has one of the widest host ranges of any plant pathogen, with over 1,000 host plant species (39), viruliferous thrips may be produced on a wide range of plants in the vicinity of crop fields (25) and then disperse into crop fields. Viruliferous thrips are able to transmit the virus within a few minutes of feeding on a healthy plant (65). Because of this vector-virus relationship, most TSW in tomato fields is a result of primary spread of the disease from adult thrips migrating into crop fields $(20,41)$. Therefore, a key to managing TSW is to limit movement of viruliferous thrips into crop fields and minimize their feeding on healthy plants.

Eight species of thrips in the genera of Frankliniella and Thrips are recognized as vectors of TSWV $(3,6,64)$. Three of these vectors species, $F$. occidentalis, $F$. fusca, and $F$. bispinosa, commonly infest tomatoes in northern Florida and southern Georgia (48,50). Another species, F. tritici, commonly occurs in tomatoes. Although it is not a vector of TSWV (2), its abundance and morphological similarity to the vector species make it a management concern for growers and crop consultants. Because these species of thrips display different population dynamics in agroecosystems $(18,19,49)$, variation in species-specific treatment effects must be assessed in developing any management program.

Many plants produce volatile essential oils that are thought to function as defenses against pathogens and insect herbivores. These naturally occurring substances are known to have a wide range of biological activities, including toxicity and repellency to certain insect pests (28). Because of these toxic and/or repellent effects, certain essential oils historically have been used as pesticides against stored grain pests and biting flies $(8,29,37)$. Recent work has examined the potential of essential oils to protect crops from pests such as thrips, whiteflies, aphids, caterpillars, and spider mites $(10,12,14,26)$. Still, widespread commercialization of plant essential oils as crop protectants has lagged, often because critical data on their efficacy and optimal application methods are lacking $(27,61)$.

Although applications of essential oils as commercial crop protectants have been limited to date, many of these essential oils are safe to humans and currently are used widely in the food and cosmetic industries. Further, with their low mammalian toxicity and low potential for other negative environmental effects $(17,28)$, the use of essential oils as crop protectants is highly appealing. The effects of individual oils or their constituents on specific target pests can differ depending on their particular mode of action (28). In preliminary labora- 
tory trials, we have found that geraniol, lemongrass oil, and tea tree oil are highly repellent to $F$. occidentalis adults (47). The monoterpene geraniol is a component of the essential oil of numerous plants. Lemongrass oil is steam distilled from Cymbopogon flexuosus (Poaceae) and contains geraniol, although its major constituent is geranial (33). Tea tree oil is steam distilled from Melaleuca alternifolia (Myrtaceae), and its major component is the terpene terpinen-4-ol (57). Further studies are needed to establish and optimize their use in the field and enhance their potential for commercial development for specific pests.

Another naturally derived material used as a crop protectant is kaolin, which can be sprayed onto plants, and leaves a whitish particle film residue. The active ingredient in the commercial formulation of kaolin that we used (Surround WP, Engelhard, Iselin, $\mathrm{NJ}$ ) is a white, hydrophilic aluminosilicate mineral $\left(\mathrm{Al}_{4} \mathrm{Si}_{4} \mathrm{O}_{10}(\mathrm{OH})_{8}\right)$. Kaolin-based particle films were developed originally for horticultural applications to reduce heat stress and sunburn damage in fruit trees $(21,23)$. It has since been reported to reduce foliar diseases in various crops and suppress some insect pests (22).

Kaolin may have several modes of action against insect pests. When sprayed on plants, kaolin alters plant color, which may reduce plant apparency to host seeking insects (44). Kaolin also can increase ultraviolet light reflectance (24), which has been shown to deter Frankliniella thrips from alighting on plants $(34,58)$. The film layer created by kaolin forms a physical barrier to insects that may interfere with insect movement and feeding $(31,42)$. Furthermore, feeding and oviposition may be hindered by particles adhering to the insect body $(9,24)$.

The potential of using plant essential oils and kaolin for control of TSW has not been investigated before our studies. Our preliminary data (46) led us to hypothesize that kaolin and geraniol, lemongrass oil, and tea tree oil could deter thrips from colonizing and/or feeding on tomato plants and thereby reduce the incidence of TSW in field grown tomatoes.

\section{MATERIALS AND METHODS}

Field experiments. Field experiments were conducted at the North Florida Research and Education Center (Quincy, Gadsden Co., FL) during spring of 2005 and 2006. The soil was an Orangeburg loamy fine sand. Plots were moldboard plowed and double disked in early March. Fertilizer was disk-incorporated in the 91cm-wide bed areas at the rate of 218-29$181 \mathrm{~kg} / \mathrm{ha}$ N-P-K. Raised beds were $10 \mathrm{~cm}$ in height and $91.4 \mathrm{~cm}$ in width, with 1.83 $\mathrm{m}$ row spacing and covered with black polyethylene mulch (Pliant, Bloomington, IN), which is the standard mulch for spring tomato crops in north Florida. Plots were fumigated at mulch application with a combination of methyl bromide $(67 \%)$ and chloropicrin $(33 \%)$ at $45 \mathrm{~g} / \mathrm{m}^{2}$.

Tomatoes (cultivar FL-47) were transplanted into the raised beds on 29 March 2005 and 23 March 2006. There was 0.51 $\mathrm{m}$ between plants. Plants were irrigated by drip irrigation. Fungicides to control foliar pathogens and Bacillus thuringiensis insecticides to control caterpillar pests were applied as needed to promote good plant growth.

The experimental design for each experiment was a randomized complete block with four replications. Plots consisted of two adjacent beds, each $8.67 \mathrm{~m}$ long, for an initial density of 36 plants per plot. All plots were separated by $5.5 \mathrm{~m}$.

Essential oil and kaolin treatments. Treatments were applied in a $5 \times 2$ factorial arrangement, with 5 essential oil and 2 kaolin treatments. The three plant essential oils, geraniol, lemongrass oil, and tea tree oil (Prima Fleur, San Rafael, CA), were applied at $250 \mathrm{ppm}(162.5 \mathrm{ml} / \mathrm{ha})$ twice per week and were compared with a grower standard insecticide treatment and a control treatment. Control plots received a treatment containing $70 \%$ ethanol $(0.1 \% \mathrm{vol} / \mathrm{vol})$ and detergent $(0.01 \%$ $\mathrm{vol} / \mathrm{vol}$ ), which was the base solution for treatments containing the essential oils. In 2005, the grower standard insecticide treatment consisted of applications of spinosad (0.14 kg a.i./ha, Spintor 2SC, Dow Agrosciences, Indianapolis, IN) rotated on a weekly basis with a combination of beta-cyfluthrin $(0.025 \mathrm{~kg}$ a.i./ha, Baythroid XL, Bayer CropSciences, Research Triangle Park, NC) and endosulfan (0.5 kg a.i./ha, Endosulfan 3EC, Bayer CropSciences). In 2006, endosulfan was omitted from the grower standard treatments.

For plots receiving kaolin, kaolin (Surround WP, BASF, Florham Park, NJ) was mixed with the appropriate essential oil treatment at a rate of $28 \mathrm{~kg} / \mathrm{ha}$ per week. Foliar applications were made using a 5nozzle tomato boom and backpack, $\mathrm{CO}_{2^{-}}$ pressurized at $414 \mathrm{kPa}$ and calibrated at 650 liters/ha. Applications were made from 8 April to 7 June 2005 and from 10 April to 1 June 2006.

Data collection. Incidence of TSW was assessed every 10 days, from transplanting until harvest, by visually inspecting each plant for symptoms of the disease. Diagnostic tests for TSWV (TSWV Immunostrip, Agdia, Elkhart, IN) were performed on 5 to 10 symptomatic plants at each assessment to verify infection. Randomly selected nonsymptomatic plants were also tested on each sample date as negative controls. TSWV-infected plants were marked on each assessment date so that disease progression could be monitored over the course of the season and the area under the disease progress curve (AUDPC) could be determined (11).
Population densities of thrips were estimated twice weekly by collecting 10 flowers at random from each of the 40 plots in the experiments. Collections were made 2 to 3 days after treatments were applied to plants, with flowers taken from one bed of each plot. Flowers were immediately placed in $70 \%$ ethanol and returned to the laboratory for processing. Thrips were extracted from flowers, and adults were sexed and identified to species. The total numbers of thrips larvae were recorded because individuals could not be identified to species.

Mature green and mature fruit were harvested from the center 12 plants on the bed of each plot opposite the bed used for thrips collections on three dates in 2005 and graded to USDA standards (62). Weights of marketable and unmarketable yields were determined.

Data analysis. TSW incidence was analyzed using a generalized linear model, based on a binomial distribution with a logit-link function, and PROC GLIMMIX (55). Specific comparisons among treatment means were made using the least squares means (LSMEANS) option with a Bonferroni correction applied to probability values to account for the number of comparisons made and thus control the overall Type I error rate $(\alpha=0.05)$. AUDPC was analyzed using a mixed linear model (PROC MIXED, 54), with means separated as above.

To account for sampling from the same plots over time, a repeated measures randomized complete block ANOVA was used (PROC MIXED, 54) to analyze the abundance of thrips. Thrips counts were either logarithmic or square root transformed before analysis to help meet the assumptions of normality and independent variances for the ANOVA (56).

A mean weight of marketable fruit per plant was calculated for each treatment plot, and these weights were subjected to ANOVA (PROC MIXED). An estimate of the weight of marketable fruit on a per hectare basis was made based on an initial plant density of 10,764 plants per hectare minus the proportion of TSWV-infected plants because diseased plants do not produce marketable fruit. Then the mean total weight of fruit per plant was multiplied by remaining number of healthy plants. These values were $\log$ transformed before analysis by ANOVA (PROC MIXED), and means compared as described above.

\section{RESULTS}

Treatment effects on incidence of TSW. All symptomatic plants tested positive for TSWV by Immunostrip assays, and none of the nonsymptomatic plants tested were positive. Although high levels of TSW were recorded in 2005, even higher levels occurred in 2006 (Fig. 1). In 2005, disease incidence increased substantially over time, with treatment differences 
evident by the third disease assessment date (23 May) (Fig. 1A and B). There was no significant interaction between the essential oil treatments and kaolin (Table 1). For the essential oil main effect, there were significant differences among the five treatments, with grower standard having the lowest level of TSW. Kaolin led to a significant reduction in TSW incidence. Although there was not a significant interaction between the essential oil treatments and kaolin, the addition of kaolin led to significantly lower incidence of TSW for all of the essential oil treatments $(P<0.05$ LSMeans $t$ tests) except for the grower standard.

The analysis of AUDPC gave results similar to the final disease incidence analyses. Overall, AUDPC was $>30 \%$ lower with kaolin than without kaolin. Lemongrass oil and tea tree oil had significantly lower AUDPCs when applied with kaolin than without kaolin $(P<0.05)$. Those combined treatments performed as well as the grower standard, suggesting that these materials do have beneficial properties for TSW management.

Disease pressure was much higher in 2006 than in 2005, but similar patterns emerged (Fig. 1). On all disease assessment dates in 2006, TSW was lower for treatments with kaolin than for treatments without kaolin (Table 2, Fig. 1C and D).
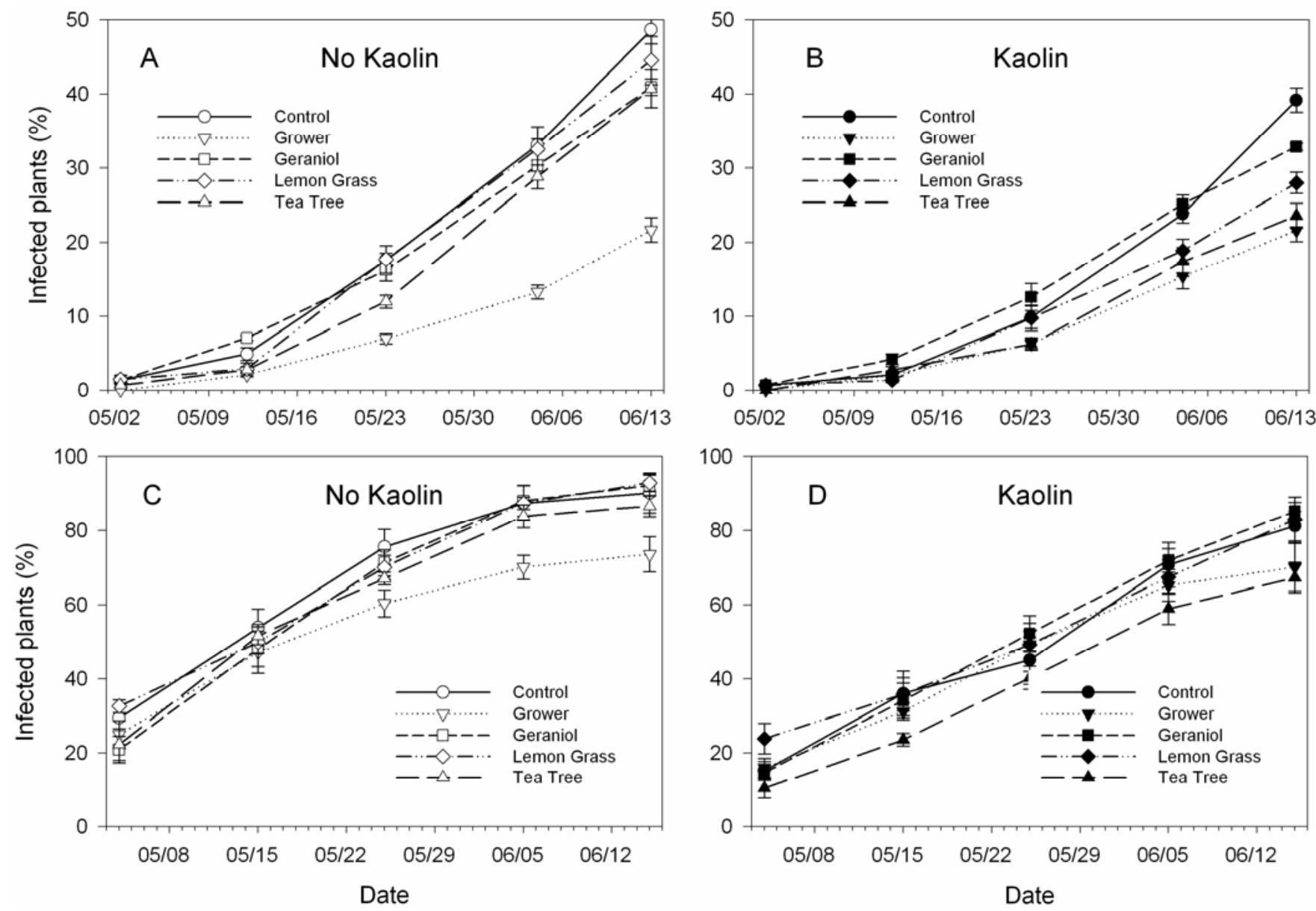

Fig. 1. Disease progress curves of tomato spotted wilt (TSW) as affected by essential oil and kaolin treatments in 2005 (A and B) and in 2006 (C and D). Note the different scales between years.

Table 1. Effects of essential oil and kaolin treatments on final incidence of tomato spotted wilt disease (TSW), area under disease progress curves (AUDPC), and marketable yield for tomatoes in 2005

\begin{tabular}{|c|c|c|c|c|c|c|c|}
\hline \multirow{2}{*}{$\frac{\text { Treatment }}{\text { No kaolin }}$} & \multicolumn{2}{|c|}{$\begin{array}{c}\text { Final TSW incidence }(\%) \\
\text { Mean } \pm \text { SEM }\end{array}$} & \multicolumn{2}{|c|}{$\begin{array}{c}\text { AUDPC } \\
\text { Mean } \pm \text { SEM } \\
\end{array}$} & \multicolumn{2}{|c|}{$\begin{array}{c}\text { Marketable yield (kg/ha) } \\
\text { Mean } \pm \text { SEM }\end{array}$} & \\
\hline & \multirow{2}{*}{\multicolumn{2}{|c|}{$48.7 \pm 4.7$}} & & & & & \\
\hline Control & & & \multicolumn{2}{|c|}{$827.7 \pm 27.5$} & \multicolumn{2}{|c|}{$16,915 \pm 2,181$} & \\
\hline Geraniol & \multicolumn{2}{|c|}{$40.9 \pm 2.8$} & \multicolumn{2}{|c|}{$771.0 \pm 83.0$} & \multicolumn{2}{|c|}{$19,375 \pm 3,097$} & \\
\hline Lemongrass oil & \multicolumn{2}{|c|}{$44.5 \pm 8.1$} & \multicolumn{2}{|c|}{$802.2 \pm 202.2$} & \multicolumn{2}{|c|}{$14,955 \pm 3,085$} & \\
\hline Tea tree oil & \multicolumn{2}{|c|}{$40.7 \pm 6.4$} & \multicolumn{2}{|c|}{$653.9 \pm 92.3$} & \multicolumn{2}{|c|}{$22,512 \pm 1,980$} & \\
\hline Grower standard & \multicolumn{2}{|c|}{$21.7 \pm 4.1$} & \multicolumn{2}{|c|}{$339.1 \pm 57.8$} & \multicolumn{2}{|c|}{$33,345 \pm 5,810$} & \\
\hline \multicolumn{8}{|l|}{ Kaolin } \\
\hline Control & \multicolumn{2}{|c|}{$39.2 \pm 4.2$} & \multicolumn{2}{|c|}{$570.5 \pm 92.9$} & \multicolumn{2}{|c|}{$21,327 \pm 3,424$} & \\
\hline Geraniol & \multicolumn{2}{|c|}{$32.8 \pm 1.2$} & \multicolumn{2}{|c|}{$604.8 \pm 106.1$} & \multicolumn{2}{|c|}{$25,209 \pm 2,090$} & \\
\hline Lemongrass oil & \multicolumn{2}{|c|}{$28.0 \pm 3.5$} & \multicolumn{2}{|c|}{$454.5 \pm 103.1$} & \multicolumn{2}{|c|}{$24,282 \pm 6,006$} & \\
\hline Tea tree oil & \multicolumn{2}{|c|}{$23.6 \pm 4.1$} & \multicolumn{2}{|c|}{$389.8 \pm 92.2$} & \multicolumn{2}{|c|}{$29,109 \pm 1,800$} & \\
\hline Grower standard & \multicolumn{2}{|c|}{$21.6 \pm 3.7$} & \multicolumn{2}{|c|}{$352.6 \pm 72.1$} & \multicolumn{2}{|c|}{$35,120 \pm 3,774$} & \\
\hline ANOVA sources & $F$ & $P$ & $F$ & $P$ & $F$ & $P$ & df \\
\hline Essential oils & 8.20 & 0.0002 & 5.18 & 0.0031 & 4.71 & 0.0051 & 4,27 \\
\hline Kaolin & 15.35 & 0.0006 & 12.53 & 0.0015 & 5.87 & 0.022 & 1,27 \\
\hline Essential oil $\times$ kaolin & 1.42 & 0.25 & 1.14 & 0.36 & 0.25 & 0.91 & 4,27 \\
\hline
\end{tabular}


There were significant differences among the essential oil treatments, with the tea tree oil and grower standard having the lowest levels of TSW. Overall, the lowest levels of TSW were in the tea tree oil plus kaolin and the two grower standard treatments (i.e., with and without kaolin) (Table 2). AUDPC was approximately $25 \%$ lower overall with kaolin than without kaolin, and each of the 5 essential oil treatments had significantly lower AUDPC with kaolin than the corresponding treatment without kaolin $(P<0.05)$.

Treatment effects on thrips populations. Thrips populations differed in overall abundance, composition, and timing of peak abundance between years. Based on overall means in the control plots, adult thrips were more abundant in 2005 (66.1 \pm 10.2 per sample) than in $2006(53.2 \pm 8.4)$. In both years, $F$. tritici was the dominant species, but that species changed from comprising over $94 \%$ of the adults collected in 2005 to comprising just $80 \%$ in 2006. The three species capable of vectoring TSWV ( $F$. occidentalis, $F$. fusca, $F$. bispinosa) were more abundant in 2006, the season with more TSW, with a total mean of $8.9 \pm 0.9$ across all control samples, than in 2005 when there was a mean of $2.8 \pm 0.4$ per control sample. Adult populations of these thrips species also peaked 1 to 2 weeks earlier in 2006 than in 2005 (Figs. 2 and 3). More importantly, each of the four Frankliniella spp. showed species-specific responses to the different essential oil and kaolin treatments.

Over the entire 2005 season, there was a significant essential oil treatment $\times$ kaolin treatment interaction on the abundance of F. tritici (Table 3). This interaction indicates that the response of $F$. tritici populations to the 5 essential oil treatments changed according to whether kaolin was applied or not. The interaction was primarily a result of the grower standard having an opposite response than the essential oils and untreated control. For those 4 treatments, the addition of kaolin resulted in significantly lower $F$. tritici abundance $(P$ $<0.005$ for each pairwise comparison). The reduction in $F$. tritici ranged from 31 to $50 \%$ in each treatment. In contrast, $F$. tritici populations were significantly higher in the grower standard insecticide treatment with kaolin $(57.6+2.3$, averaged over all sample dates) than without kaolin $(36.8+1.9, P<0.0001)$. This represents a $58 \%$ increase in abundance of $F$. tritici with kaolin in the grower standard. This increase in $F$. tritici abundance in the grower standard with kaolin also meant that the essential oils with kaolin preformed as well as or better than the grower standard with kaolin in terms of managing F. tritici (Fig. 2). In 2006, kaolin by itself (comparing control versus control + kaolin) or with insecticides (grower standard versus grower standard + kaolin) did not have an effect on F. tritici populations $(P>$
0.05). However, for each of the essential oils, the presence of kaolin significantly reduced the numbers of $F$. tritici adults ( $P$ $<0.05$ for each pairwise comparison).

$F$. occidentalis was the most abundant TSWV vector species in both 2005 and 2006. It comprised $67 \%$ of the vector species adults collected in 2005 and $89 \%$ in 2006 (Figs. 2 and 3). In 2005, the essential oil and kaolin treatments did not significantly affect $F$. occidentalis populations (Table 3, Fig. 2). However in 2006, there were significant differences among the essential oil treatments (Table 4, Fig. 3). The lowest $F$. occidentalis populations were found in the grower standard treatments, but these were not significantly lower than populations in the tea tree oil treatments.

F. bispinosa populations showed significant differences among the essential oil treatments in both years of the study (Tables 3 and 4, Figs. 2 and 3). The overall abundance of $F$. bispinosa was about $60 \%$ higher in 2006 than in 2005. In 2005, the lowest levels of $F$. bispinosa were in the control, although these levels were not significantly different from those found in the geraniol, lemongrass, and tea tree oil treatments. In contrast, the grower standard had significantly higher levels of $F$. bispinosa than the control. In 2006, the pattern differed among the essential oil treatments, with the grower standard and tea tree oil treatments having significantly lower levels of $F$. bispinosa compared with the three other treatments. Populations of F. bispinosa were not affected by kaolin treatments in either year (Tables 3 and 4).

The abundance of $F$. fusca was not affected by any of the essential oil treatments or the grower standard insecticide treatment in either 2005 or 2006 (Tables 3 and 4, Figs. 2 and 3). However, populations of $F$. fusca were significantly higher with kaolin than without kaolin. In both years, the overall abundance of $F$. fusca in kaolin treatments was approximately twice the abundance as without kaolin.
As with populations of adult thrips, the populations of Frankliniella spp. larvae changed over the course of each season as well as between seasons (Tables 3 and 4, Fig. 4). Larval populations also tended to peak earlier in 2006 than in 2005. The abundance of Frankliniella spp. larvae was significantly affected by the essential oil treatments in both 2005 and 2006. The primary difference was that larval populations were significantly lower in the grower standard treatments compared with the other essential oil treatments (Fig. 4). Kaolin did not affect the abundance of larval thrips.

Treatment effects on tomato yield. In 2005 , total marketable yield was significantly affected both by the essential oil and kaolin treatments (Table 1). The grower standard treatments had the highest yields on a per hectare basis, but these were not significantly greater than the tea tree oil plus kaolin treatment. Overall, kaolin significantly improved yield. Neither the essential oil nor kaolin treatments affected the yield per plant $(P>0.05$ for all tests), indicating that differences in total yield on an area basis were largely from treatments affecting the number of healthy, harvestable plants rather than the treatments affecting individual plant physiology. Because of the high levels of disease for all treatments in 2006, yield determinations could not be made.

\section{DISCUSSION}

Little detailed information exists for the effects of essential oils and kaolin on populations of thrips or the incidence of TSW. Our results show that the combination of essential oils and kaolin, especially tea tree oil, can significantly reduce the incidence of TSW. Tea tree oil plus kaolin was as effective as standard broad spectrum insecticides on the incidence of TSW and yield of field grown tomatoes. Although the essential oils combined with kaolin had positive effects on the incidence of TSW, there were no clear relationships

Table 2. Effects of essential oil and kaolin treatments on final incidence of tomato spotted wilt disease (TSW) and area under disease progress curves (AUDPC) for tomatoes in 2006

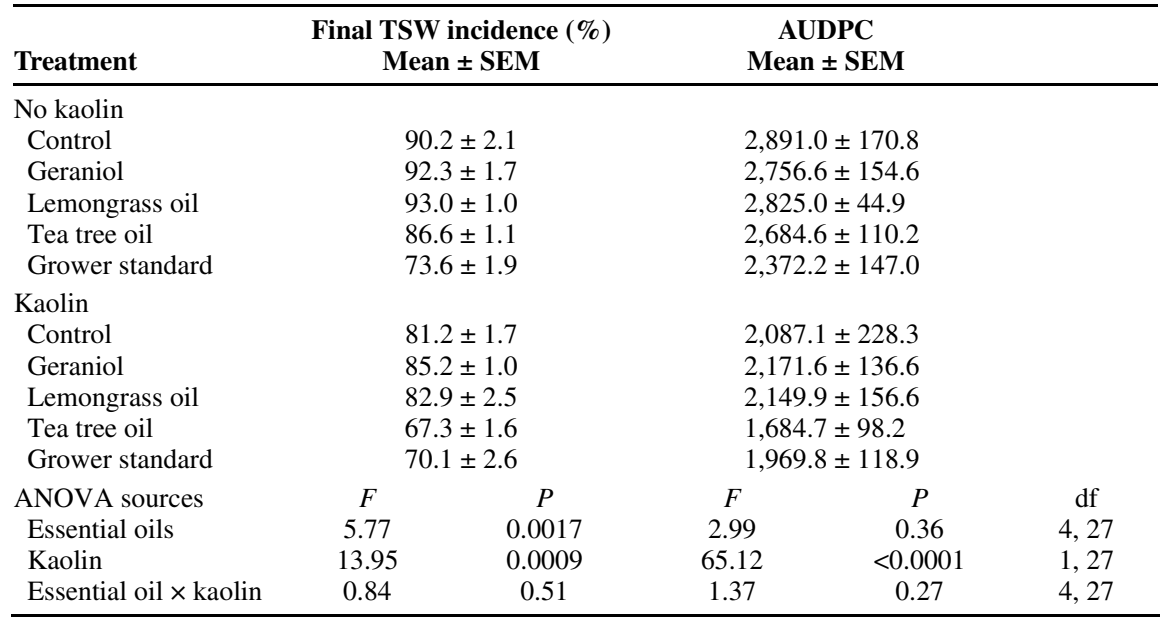


between treatments and populations of the thrips vectors of TSWV.

Certain plant essential oils and their constituents have been shown to be repellent to F. occidentalis in laboratory assays
(35; S. Reitz, G. Maiorino, A. Crescenzi, and M. T. Momol, unpublished), but their effectiveness in field situations has not been clearly demonstrated previously. Van Tol et al. (63) did conclude that the essential oil from Origanum majorana repelled Thrips tabaci from white sticky traps in a small scale field trial but that tea tree oil did not. However it may not be possible to generalize the effects on one thrips species to ef-
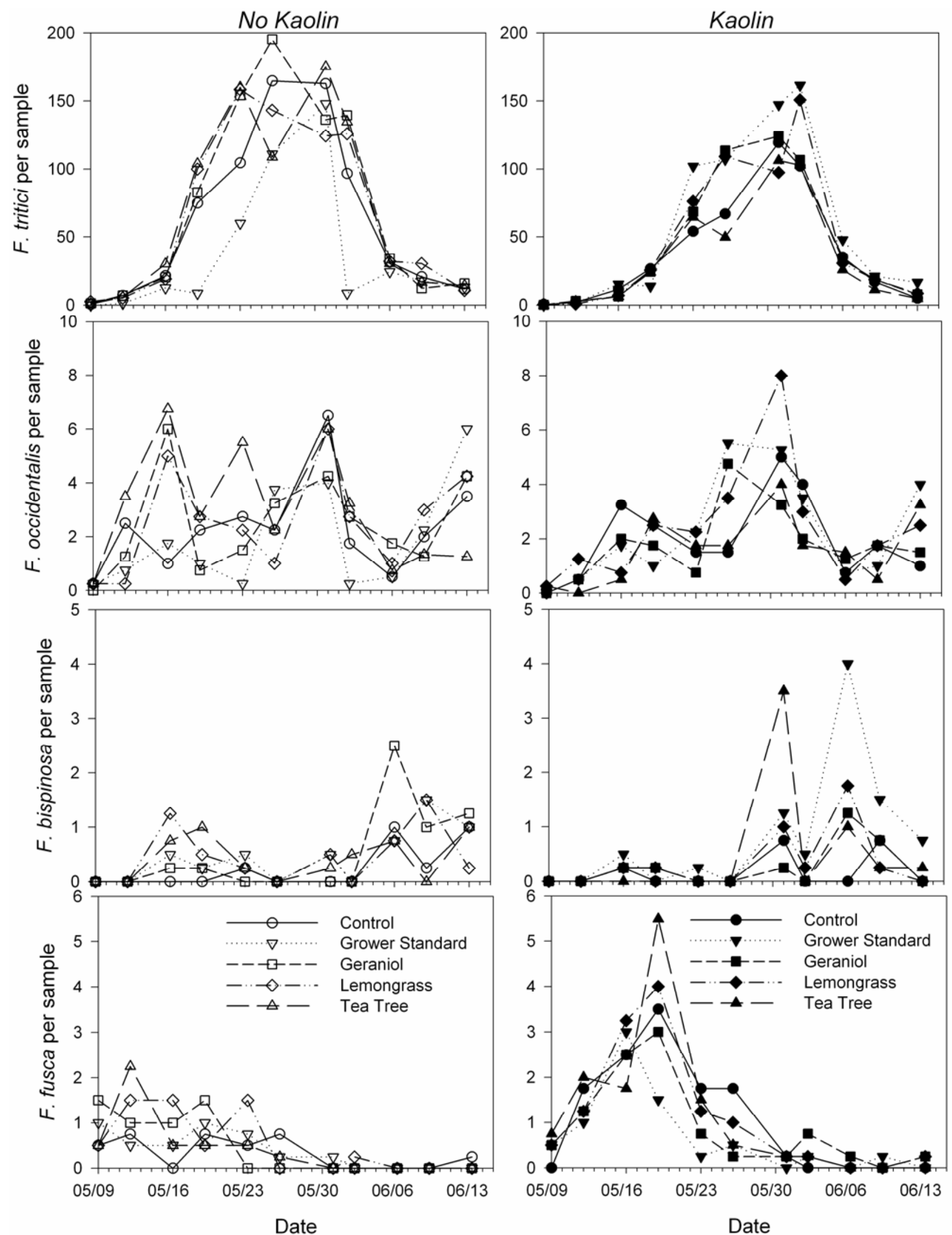

Fig. 2. Seasonal abundance of adults of Frankliniella spp. in tomato flowers as affected by essential oils and kaolin in 2005. Note the different scales for each species. 
fects on other species, as opposite responses to the same plant volatiles have been observed for T. tabaci and F. occidentalis (16).

The strong repellent properties of geraniol, lemongrass oil, and tea tree oil that we have observed in laboratory assays suggested that field applications may reduce the abundance of thrips in tomatoes. Although our results did not show a clear effect of the essential oils on the thrips populations, the final disease incidence suggests that the essential oils that we tested have activity against vector thrips when applied with kaolin. Essential oils tend to have high volatility and thus poten-
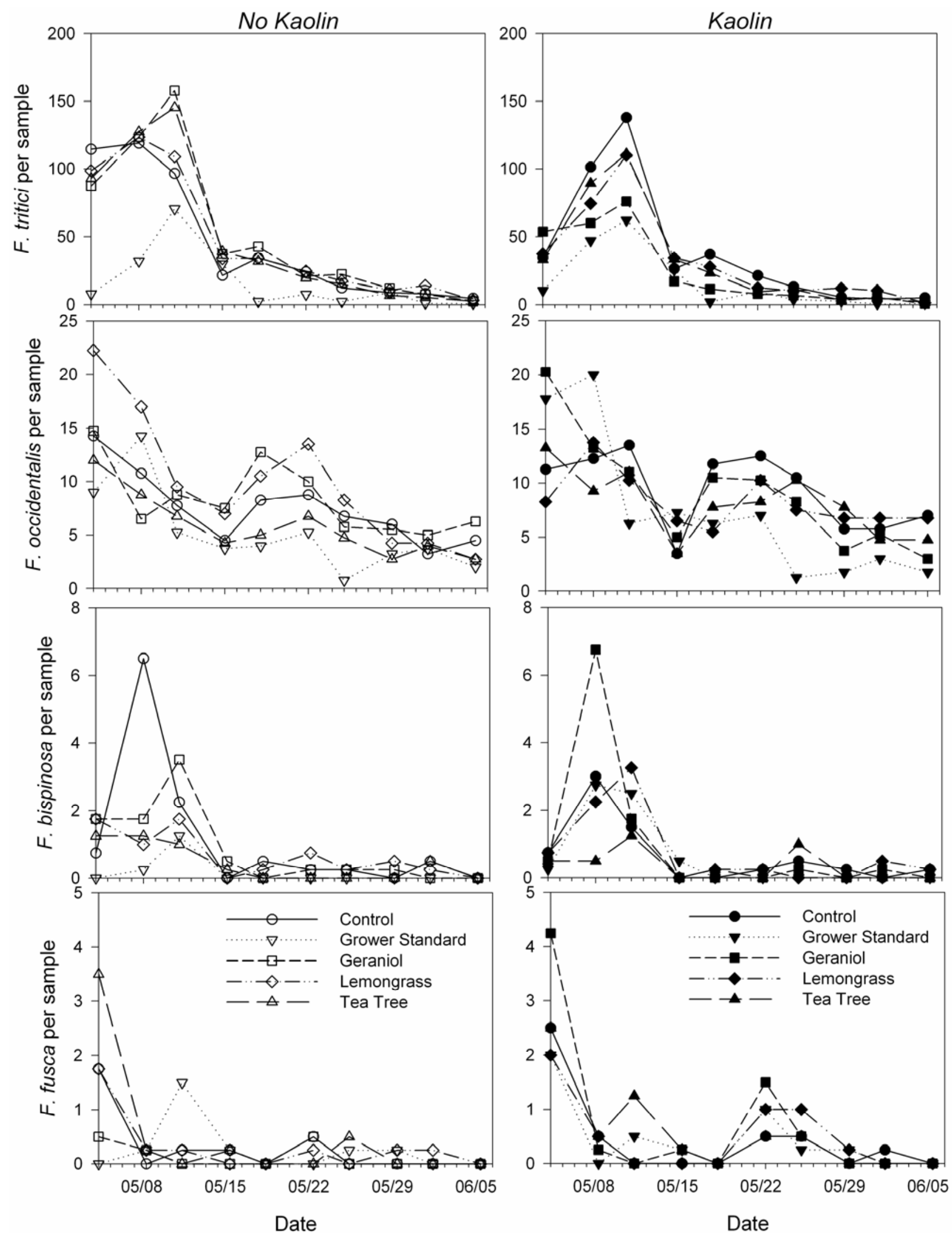

Fig. 3. Seasonal abundance of adults of Frankliniella spp. in tomato flowers as affected by essential oils and kaolin in 2006. Note the different scales for each species. 
Table 3. Analysis of variance (ANOVA) results for the effects of essential oils and kaolin on Frankliniella spp. in tomatoes in 2005

\begin{tabular}{|c|c|c|c|c|c|c|c|c|c|c|c|}
\hline \multirow[b]{2}{*}{ ANOVA sources } & \multicolumn{2}{|c|}{ F. tritici } & \multicolumn{2}{|c|}{ F. occidentalis } & \multicolumn{2}{|c|}{ F. bispinosa } & \multicolumn{2}{|c|}{ F. fusca } & \multicolumn{2}{|c|}{ Larvae } & \multirow[b]{2}{*}{ df } \\
\hline & $\boldsymbol{F}$ & $\boldsymbol{P}$ & $\boldsymbol{F}$ & $\boldsymbol{P}$ & $\boldsymbol{F}$ & $\boldsymbol{P}$ & $F$ & $P$ & $\boldsymbol{F}$ & $\boldsymbol{P}$ & \\
\hline Essential oils & 4.11 & 0.010 & 0.30 & 0.88 & 2.75 & 0.048 & 0.94 & 0.46 & 4.49 & 0.0065 & 4,27 \\
\hline Kaolin & 40.97 & $<0.0001$ & 2.14 & 0.16 & 0.56 & 0.46 & 28.80 & $<0.0001$ & 2.59 & 0.12 & 1,27 \\
\hline Essential oil $\times$ kaolin & 16.81 & $<0.0001$ & 0.99 & 0.43 & 1.00 & 0.43 & 0.74 & 0.57 & 1.52 & 0.22 & 4,27 \\
\hline Date & 287.06 & $<0.0001$ & 15.20 & $<0.0001$ & 11.15 & $<0.0001$ & 20.19 & $<0.0001$ & 71.89 & $<0.0001$ & 10,299 \\
\hline Date $\times$ essential oil & 4.03 & $<0.0001$ & 0.96 & 0.56 & 1.08 & 0.39 & 0.88 & 0.67 & 2.08 & 0.0003 & 40,299 \\
\hline Date $\times$ kaolin & 11.38 & $<0.0001$ & 1.48 & 0.14 & 1.98 & 0.035 & 7.49 & $<0.0001$ & 4.91 & $<0.0001$ & 10,299 \\
\hline $\begin{array}{l}\text { Date } \times \text { essential oil } \times \\
\text { kaolin }\end{array}$ & 2.75 & $<0.0001$ & 1.10 & 0.32 & 1.18 & 0.22 & 0.81 & 0.75 & 1.72 & 0.0065 & 40,299 \\
\hline
\end{tabular}

Table 4. Analysis of variance (ANOVA) results for the effects of essential oils and kaolin on Frankliniella spp. in tomatoes in 2006

\begin{tabular}{|c|c|c|c|c|c|c|c|c|c|c|c|}
\hline \multirow[b]{2}{*}{ ANOVA sources } & \multicolumn{2}{|c|}{ F. tritici } & \multicolumn{2}{|c|}{ F. occidentalis } & \multicolumn{2}{|c|}{ F. bispinosa } & \multicolumn{2}{|c|}{ F. fusca } & \multicolumn{2}{|c|}{ Larvae } & \multirow[b]{2}{*}{ df } \\
\hline & $F$ & $P$ & $F$ & $P$ & $F$ & $P$ & $F$ & $P$ & $F$ & $P$ & \\
\hline Essential oils & 31.34 & $<0.0001$ & 4.12 & 0.0099 & 4.59 & 0.0059 & 0.37 & 0.83 & 10.56 & $<0.0001$ & 4,27 \\
\hline Kaolin & 40.45 & $<0.0001$ & 1.73 & 0.20 & 0.01 & 0.94 & 10.86 & 0.0028 & 0.19 & 0.66 & 1,27 \\
\hline Essential oil $\times$ kaolin & 5.08 & 0.0035 & 0.77 & 0.55 & 1.43 & 0.25 & 0.57 & 0.68 & 0.67 & 0.62 & 4,27 \\
\hline Date & 180.05 & $<0.0001$ & 20.20 & $<0.0001$ & 35.49 & $<0.0001$ & 24.99 & $<0.0001$ & 12.42 & $<0.0001$ & 9,270 \\
\hline Date $\times$ essential oil & 3.24 & $<0.0001$ & 1.48 & 0.046 & 1.77 & 0.0060 & 1.04 & 0.42 & 1.68 & 0.012 & 36,270 \\
\hline Date $\times$ kaolin & 3.76 & $<0.0001$ & 0.56 & 0.83 & 1.06 & 0.39 & 2.86 & 0.0031 & 1.39 & 0.19 & 9,270 \\
\hline $\begin{array}{l}\text { Date } \times \text { essential oil } \times \\
\text { kaolin }\end{array}$ & 1.38 & 0.081 & 0.97 & 0.53 & 1.72 & 0.0091 & 1.26 & 0.15 & 1.05 & 0.40 & 36,270 \\
\hline
\end{tabular}

tially limited persistence under field conditions (29). Mass flights of thrips into tomato fields repeatedly occur in the spring (53). Thus, sampling for thrips 2 to 3 days after treatment applications may not have detected shorter term deterrent or antifeedant effects of the essential oils on thrips.

Rates of TSWV infection were consistently lower with kaolin than without kaolin. This was despite the fact that overall mean numbers of vector species adults were similar between kaolin and no kaolin treatments in both 2005 and 2006. Although other vectors of plant pathogens have been successfully reduced by kaolin treatments $(4,43-45,60)$, kaolin treatments have not always effectively reduced insect vectors of plant diseases (reviewed in 22).

Based on overall populations, F. occidentalis was the most important vector present in our system. F. fusca, which had significantly higher populations in the kaolin treated plots, was the second most abundant vector species. We suspect that kaolin interfered with thrips feeding behavior and transmission of TSWV, so that although kaolin did not lead to a reduction in the overall abundance of vector species adults, it did reduce the incidence of TSW. Previous research has shown that other types of film coatings (e.g., oil based or silicone sprays) can reduce feeding and ultimately virus transmission by $F$. occidentalis in laboratory tests (1). Liu and Trumble (36) showed that kaolin reduces feeding activity of Bactericerca cockerelli and increases the amount of time it spends grooming and resting. However, kaolin did not result in greater locomotor activity of $B$. cockerelli or time spent off the host plant. Therefore, kaolin may not directly affect observed insect populations while still interfering with disease transmission.

Kaolin has been shown to reduce the incidence of Beet curly top virus, a curtovirus, which is transmitted by the beet leafhopper Circulifer tenellus (15). Although Creamer et al. (15) did not report effects on numbers of beet leafhoppers, disease incidence was reduced by as much as $16 \%$. Similar to our findings, they found that kaolin did not affect yield per plant, but differences in numbers of harvestable plants led to differences in total yield. Feeding on kaolin treated plants induces significant mortality in Homalodisca virtripennis, the most important vector of Xylella fastidiosus, the causal agent of Pierce's disease (60). This mortality has resulted in lower levels of Pierce's disease in grapevines. Evidently, the ability of kaolin to affect insect vectors is species specific, and these interspecific differences must be evaluated when considering using kaolin in a pest management program.

We found that adults of the vector species were much more abundant in 2006 than in 2005, and importantly, these vector species peaked earlier in 2006 than in 2005. Clearly, the higher populations were important in causing greater disease incidence in 2006. In addition, the difference in temporal dynamics may have been a contributing factor in the much higher levels of TSW in 2006, as younger plants are often more susceptible to infection than are older plants $(7,40)$. As populations declined, the rate of new infections declined in 2006, which was opposite the pattern in 2005, where rates of new infections increased later in the season.

Although standard insecticides may not suppress TSW because of repeated immigration of vectors into fields, growers still make applications to minimize the risk of secondary spread of TSW from thrips reproducing within crop fields. However, the lack of subsequent secondary peaks in the abundance of adults following larval peaks indicates that successful reproduction of thrips within tomatoes was low, and therefore secondary spread of TSW from within fields was not significant. These results and those from other studies of thrips reproduction in tomato $(13,48)$ suggest that the use of essential oils and kaolin in lieu of standard insecticides would not pose a greater risk for secondary spread of TSW.

In this study, we sought to integrate the use of two types of naturally occurring crop protectants, kaolin particle film coatings and plant essential oils, into a more environmentally benign and sustainable management program for tomatoes. Certain essential oils can suppress other foliar tomato pathogens $(30,32,67)$. Likewise, kaolin can reduce foliar pathogens in certain crops $(24,59)$, and it can reduce sunburn damage in tomatoes (52). Therefore, plant essential oils and kaolin used for thrips and TSW management may have additional benefits in tomato production. Understanding the effects of novel management tools on plant health, vigor and yield are particularly valuable when planning cost effective programs for high input crops such as tomato.

The results of our field studies show that TSWV continues to be a severe problem facing tomato production in the southern United States. Several management tactics, such as ultraviolet reflective mulches, systemic acquired resistance inducers, and host plant tolerance and resistance, have shown promise in limiting TSW in field grown tomatoes $(38,50)$. Yet no single management tactic has proven to be com- 

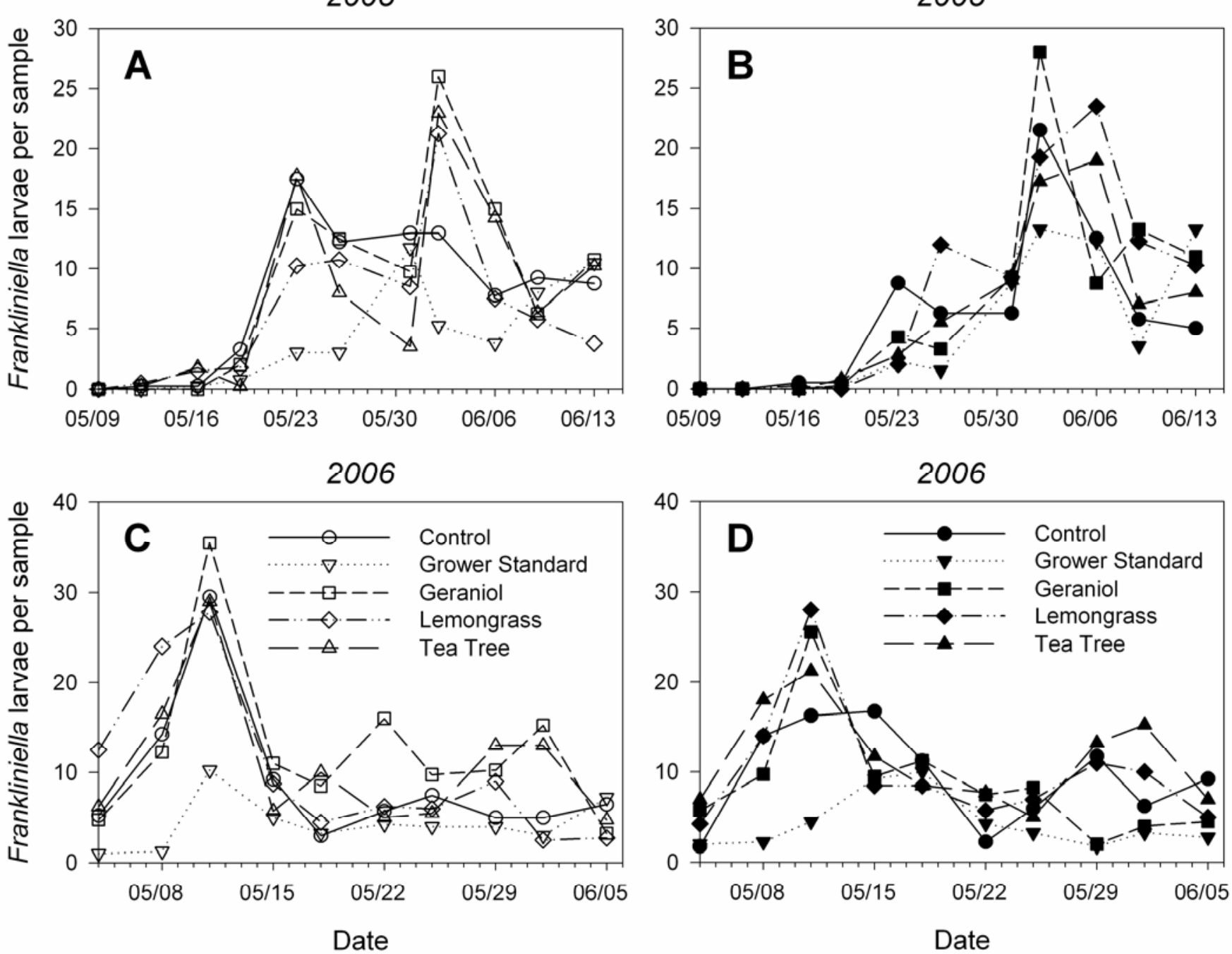

Fig. 4. Seasonal abundance of Frankliniella spp. larvae in tomato flowers as affected by essential oils and kaolin in 2005 (A and B) and in 2006 (C and D). Note the different scales between years.

pletely successful in suppressing TSW. The combination of kaolin and tea tree oil offers another potential tactic for mitigating losses from this pathogen and maintaining yield in a manner that is less environmentally disruptive than the use of broad spectrum insecticides. The potential ancillary benefits and low cost of these materials suggest they could be incorporated into tomato production systems. Further research to improve the efficacy of these materials is warranted to determine their applicability in tomato production.

\section{ACKNOWLEDGMENTS}

We thank Laura Ritchie, Hank Dankers, Jackie Snell, Don Berger, Kristen Bowers, and Marcus Edwards for technical assistance. We appreciate the comments of Alex Csinos, University of Georgia, and Moses Kairo, Florida A\&M University, which have improved the manuscript. This research was supported in part with funds provided by the Gadsden County Tomato Growers Association and a grant from the USDA Sustainable Agriculture Research and Education program.

\section{LITERATURE CITED}

1. Allen, W. R., Tehrani, B., and Luft, R. 1993. Effect of horticultural oil, insecticidal soap, and film-forming products on the western flower thrips and the tomato spotted wilt virus. Plant Dis. 77:915-918.

2. Assis Filho, F. M., Stavisky, J., Reitz, S. R., Deom, C. M., and Sherwood, J. L. 2005. Midgut infection by tomato spotted wilt virus and vector incompetence of Frankliniella tritici. J. Appl. Entomol. 129:548-550.

3. Avila, Y., Stavisky, J., Hague, S., Funderburk, J., Reitz, S., and Momol, T. 2006. Evaluation of Frankliniella bispinosa (Thysanoptera: Thripidae) as a vector of the Tomato spotted wilt virus in pepper. Fla. Entomol. 89:204-207.

4. Bar-Joseph, M., and Frenkel, H. 1983. Spraying citrus plants with kaolin suspensions reduces colonization by the spiraea aphid (Aphis citricola van der Goot) (lime Citris auranticola). Crop Prot. 2:371-374.

5. Bauske, E. M. 1998. Southeastern tomato growers adopt integrated pest management. HortTechnology 8:40-44.

6. Borbon, C. M., Gracia, O., and Piccolo, R. 2006. Relationships between Tospovirus incidence and thrips populations on tomato in Mendoza, Argentina. J. Phytopathol. 154:9399.
7. Buiel, A. A. M., and Parlevliet, I. E. 1996 Mature plant and tissue resistance in the groundnut-peanut bud necrosis virus system. Euphytica 91:213-217.

8. Burfield, T., and Reekie, S. L. 2005. Mosquitoes, malaria and essential oils. Int. J. Aromatherapy 15:30-41.

9. Bürgel, K., Daniel, C., and Wyss, E. 2005. Effects of autumn kaolin treatments on the rosy apple aphid, Dysaphis plantaginea (Pass.) and possible modes of action. J. Appl. Entomol. 129:311-314.

10. Calmasur, O., Aslan, I., and Sahin, F. 2006. Insecticidal and acaricidal effect of three Lamiaceae plant essential oils against Tetranychus urticae Koch and Bemisia tabaci Genn. Ind. Crop. Prod. 23:140-146.

11. Campbell, C. L., and Madden, L. V. 1990. Introduction to Plant Disease Epidemiology. John Wiley \& Sons, New York.

12. Chiasson, H., Vincent, C., and Bostanian, N. J. 2004. Insecticidal properties of a Chenopodium-based botanical. J. Econ. Entomol. 97:1378-1383.

13. Cho, K., Walgenbach, J. F., and Kennedy, G. G. 2000. Daily and temporal occurrence of Frankliniella spp. (Thysanoptera: Thripidae) on tomato. Appl. Entomol. Zool. 35:207-214.

14. Choi, W. I., Lee, E. H., Choi, B. R., Park, H. 
M., and Ahn, Y. J. 2003. Toxicity of plant essential oils to Trialeurodes vaporariorum (Homoptera: Aleyrodidae). J. Econ. Entomol. 96:1479-1484

15. Creamer, R., Sanogo, S., El-Sebai, O. A., Carpenter, J., and Sanderson, R. 2005. Kaolinbased foliar reflectant affects physiology and incidence of beet curly top virus but not yield of chile pepper. HortScience 40:574-576.

16. de Kogel, W. J., and Koschier, E. H. 2002. Thrips responses to plant odours. Pages 133140 in: Thrips and Tospoviruses: Proc. 7th Int. Sympos. Thysanoptera, 7th. Reggio Calabria, Italy. R. Marullo and L. A. Mound, eds. Australian National Insect Collection, Canberra.

17. Ebbon, G. P. 2002. Environmental and health aspects of agricultural spray oils. Pages 232246 in: Spray Oils Beyond 2000. G. A. C. Beattie, D. M. Watson, M. L. Stevens, D. J. Rae, and R. N. Spooner-Hart, eds. University of Western Sydney Press, Sydney, NSW.

18. Eckel, C. S., Cho, K., Walgenbach, J. F., Kennedy, G. G., and Moyer, J. W. 1996. Variation in thrips species composition in field crops and implications for tomato spotted wilt epidemiology in North Carolina. Entomol. Exp. Appl. 78:19-29.

19. Funderburk, J., Stavisky, J., and Olson, S. 2000. Predation of Frankliniella occidentalis (Thysanoptera: Thripidae) in field peppers by Orius insidiosus (Hemiptera: Anthocoridae). Environ. Entomol. 29:376-382.

20. Gitaitis, R. D., Dowler, C. C., and Chalfant, R. B. 1998. Epidemiology of tomato spotted wilt in pepper and tomato in southern Georgia. Plant Dis. 82:752-756.

21. Glenn, D. M., Prado, E., Erez, A., McFerson, J., and Puterka, G. J. 2002. A reflective, processed-kaolin particle film affects fruit temperature, radiation reflection, and solar injury in apple. J. Am. Soc. Hortic. Sci. 127:188-193.

22. Glenn, D. M., and Puterka, G. J. 2005. Particle films: A new technology for agriculture. Hortic. Rev. 31:1-44.

23. Glenn, D. M., Puterka, G. J., Drake, S. R., Unruh, T. R., Knight, A. L., Baherle, P., Prado, E., and Baugher, T. A. 2001. Particle film application influences apple leaf physiology, fruit yield, and fruit quality. J. Am. Soc. Hortic. Sci 126:175-181.

24. Glenn, D. M., Puterka, G. J., Vanderzwet, T., Byers, R. E., and Feldhake, C. 1999. Hydrophobic particle films: A new paradigm for suppression of arthropod pests and plant diseases. J. Econ. Entomol. 92:759-771.

25. Groves, R. L., Walgenbach, J. F., Moyer, J. W., and Kennedy, G. G. 2002. The role of weed hosts and tobacco thrips, Frankliniella fusca, in the epidemiology of Tomato spotted wilt virus. Plant Dis. 86:573-582

26. Hummelbrunner, L. A., and Isman, M. B. 2001. Acute, sublethal, antifeedant, and synergistic effects of monoterpenoid essential oil compounds on the tobacco cutworm, Spodoptera litura (Lep., Noctuidae). J. Agric. Food Chem. 49:715-720.

27. Isman, M. B. 1997. Neem and other botanical insecticides: Barriers to commercialization. Phytoparasitica 25:339-344

28. Isman, M. B. 2000. Plant essential oils for pest and disease management. Crop Prot. 19:603608 .

29. Isman, M. B. 2006. Botanical insecticides, deterrents, and repellents in modern agriculture and an increasingly regulated world. Annu. Rev. Entomol. 51:45-66.

30. Ji, P., Momol, M. T., Olson, S. M., Pradhanang, P. M., and Jones, J. B. 2005. Evaluation of thymol as biofumigant for control of bacterial wilt of tomato under field conditions. Plant Dis. 89:497-500.

31. Jifon, J. L., and Syvertsen, J. P. 2003. Kaolin particle film applications can increase photosynthesis and water use efficiency of 'ruby red' grapefruit leaves. J. Am. Soc. Hortic. Sci. 128:107-112.

32. Kalemba, D., and Kunicka, A. 2003. Antibacterial and antifungal properties of essential oils. Curr. Med. Chem. 10:813-829.

33. Khanuja, S. P. S., Shasany, A. K., Pawar, A., Lal, R. K., Darokar, M. P., Naqvi, A. A., Rajkumar, S., Sundaresan, V., Lal, N., and Kumar, S. 2005. Essential oil constituents and RAPD markers to establish species relationship in Cymbopogon Spreng. (Poaceae). Biochem. Syst. Ecol. 33:171-186.

34. Kirk, W. D. J. 1984. Ecologically selective coloured traps. Ecol. Entomol. 9:35-41.

35. Koschier, E. H., de Kogel, W. J., and Visser, J. H. 2000. Assessing the attractiveness of volatile plant compounds to western flower thrips Frankliniella occidentalis. J. Chem. Ecol. 26:2643-2655.

36. Liu, D., and Trumble, J. T. 2004. Tomato psyllid behavioral responses to tomato plant lines and interactions of plant lines with insecticides. J. Econ. Entomol. 1078-1085.

37. Momol, M. T., Olson, S. M., Funderburk, J. E., and Marois, J. J. 2003. Integrated management of tomato spotted wilt on tomoto. (Abstr.) Phytopathology 93:S115.

38. Momol, M. T., Olson, S. M., Funderburk, J. E., Stavisky, J., and Marois, J. J. 2004. Integrated management of tomato spotted wilt on fieldgrown tomatoes. Plant Dis. 88:882-890.

39. Parrella, G., Gognalons, P., Gebre-Selassiè, K., Vovlas, C., and Marchoux, G. 2003. An update of the host range of Tomato Spotted Wilt Virus. J. Plant Pathol. 85 (suppl. 1):1-38.

40. Paterson, R. G., Scott, S. J., and Gergerich, R. C. 1989. Resistance in two Lycopersicon spp. to an Arkansas USA isolate of Tomato spotted wilt virus. Euphytica 43:173-178.

41. Puche, H., Berger, R. D., and Funderburk, J. E. 1995. Population dynamics of Frankliniella species (Thysanoptera: Thripidae) thrips and progress of spotted wilt in tomato fields. Crop Prot. 14:577-583.

42. Puterka, G. J., Glenn, D. M., and Pluta, R. C. 2005. Action of particle films on the biology and behavior of pear psylla (Homoptera: Psyllidae). J. Econ. Entomol. 98:2079-2088.

43. Puterka, G. J., Glenn, D. M., Sekutowski, D. G., Unruh, T. R., and Jones, S. K. 2000. Progress toward liquid formulations of particle films for insect and disease control in pear. Environ. Entomol. 29:329-339.

44. Puterka, G. J., Reinke, M., Luvisi, D., Ciomperik, M. A., Bartels, D., Wendel, L., and Glenn, D. M. 2003. Particle film, Surround WP, effects on glassy-winged sharpshooter behavior and its utility as a barrier to sharpshooter infestations in grape. Plant Health Progress doi 10:2003-0321.

45. Reich, J. A. 2006. Field and greenhouse studies with Acalymma and Diabrotica: Protection of cucurbits with a kaolin-based particle film: Feeding damage to cucumbers with and without cucurbitacin. M.Sc. thesis. Oregon State University, Corvallis.

46. Reitz, S., Maiorino, G., Ritchie, L., Olson, S., Sprenkel, R., Crescenzi, A., and Momol, M. T. 2006. Plant essential oils and particle films for the management of tomato spotted wilt on tomatoes. (Abstr.) Phytopathology 96:S97.

47. Reitz, S., Maiorino, G., Ritchie, L., Olson, S., Sprenkel, R., Crescenzi, A., and Momol, M. T. 2007. The effects of plant essential oils and particle films on tomato spotted wilt and thrips in tomatoes. (Abstr.) Phytopathology 97:S98.

48. Reitz, S. R. 2002. Seasonal and within plant distribution of Frankliniella thrips (Thysanoptera: Thripidae) in north Florida tomatoes. Fla. Entomol. 85:431-439.
49. Reitz, S. R., Funderburk, J. E., Hansen, E. A., Baez, I., Waring, S., and Ramachandran, S. 2002. Interspecific variation in behavior and its role in thrips ecology. Pages 133-140 in: Thrips and Tospoviruses: Proc. Int. Sympos Thysanoptera, 7th. Reggio Calabria, Italy. R. Marullo and L. A. Mound, eds. Australian National Insect Collection, Canberra.

50. Riley, D. G., and Pappu, H. R. 2004. Tactics for management of thrips (Thysanoptera: Thripidae) and tomato spotted wilt virus in tomato. J. Econ. Entomol. 97:1648-1658.

51. Rosello, S., Diez, M. J., and Nuez, F. 1996. Viral diseases causing the greatest economic losses to the tomato crop: I. The tomato spotted wilt virus - a review. Sci. Hortic. (Amsterdam) 67:117-150.

52. Saavedra Del R, G., Escaff G, M., and J., Hernández V, J. 2006. Kaolin effects in processing tomato production in Chile. Acta Hortic. 724:191-198

53. Salguero-Navas, V. E., Funderburk, J. E., Beshear, R. J., Olson, S. M., and Mack, T. P. 1991. Seasonal patterns of Frankliniella spp. (Thysanoptera: Thripidae) in tomato flowers. J. Econ. Entomol. 84:1818-1822.

54. SAS. 2004. SAS/STAT User's Guide, ver. 9.1 SAS Institute, Cary, NC.

55. SAS. 2006. SAS/STAT: The GLIMMIX Procedure. SAS Institute, Cary, NC.

56. Sokal, R. R., and Rohlf, F. J. 1995. Biometry: The Principles and Practice of Statistics in Biological Research. Freeman, New York.

57. Standen, M. D., Connellan, P. A., and Leach, D. N. 2006. Natural killer cell activity and lymphocyte activation: Investigating the effects of a selection of essential oils and components in vitro. Int. J. Aromatherapy 16:133-139.

58. Terry, L. I. 1997. Host selection, communication and reproductive behavior. Pages 65-118 in: Thrips as Crop Pests. T. Lewis, ed. CAB International, New York.

59. Thomas, A. L., Muller, M. E., Dodson, B. R. Ellersieck, M. R., and Kaps, M. 2004. A kaolin-based particle film suppresses certain insect and fungal pests while reducing heat stress in apples. J. Am. Pomol. Soc. 58:42-51

60. Tubajika, K. M., Civerolo, E. L., Puterka, G. J., Hashim, J. M., and Luvisi, D. A. 2007. The effects of kaolin, harpin, and imidacloprid on development of Pierce's disease in grape. Crop Prot. 26:92-99.

61. Ujváry, I. 2002. Transforming natural products into natural pesticides - Experience and expectations. Phytoparasitica 30:439-442.

62. USDA. 1976. United States standards for grades of fresh tomato. Pages 1-11. United States Department of Agriculture, Agricultural Marketing Service.

63. van Tol, R. W. H. M., James, D. E., de Kogel, W. J., and Teulon, D. A. J. 2007. Plant odours with potential for a push-pull strategy to control the onion thrips, Thrips tabaci. Entomol. Exp. Appl. 122:69-76.

64. Whitfield, A. E., German, T. L., and Ullman, D. E. 2005. Tospovirus-thrips interactions. Annu. Rev. Phytopathol. 43:459-489.

65. Wijkamp, I., Van De Wetering, F., Goldbach, R., and Peters, D. 1996. Transmission of tomato spotted wilt virus by Frankliniella occidentalis; median acquisition and inoculation access period. Ann. Appl. Biol. 129:303-313.

66. Wijkamp, I., Van Lent, J., Kormelink, R Goldbach, R., and Peters, D. 1993. Multiplication of tomato spotted wilt virus in its insect vector, Frankliniella occidentalis. J. Gen. Virol. 74:341-349.

67. Wilson, C. L., Solar, J. M., El Ghaouth, A., and Wisniewski, M. E. 1997. Rapid evaluation of plant extracts and essential oils for antifungal activity against Botrytis cinerea. Plant Dis. 81:204-210. 